\title{
STRATEGI PEMBELAJARAN DENGAN MODEL PENDEKATAN PADA PESERTA DIDIK AGAR TERCAPAINYA TUJUAN PENDIDIKAN DI ERA GLOBALISASI
}

\author{
Novita Eka Anggraeni ${ }^{1^{*}}$ \\ 1) Program Studi Pendidikan IPA/Jurusan Pendidikan MIPA, Fakultas Keguruan \\ Dan Ilmu Pendidikan, Universitas Jember, Indonesia \\ E-mail: novita.17jbr@gmail.com
}

\begin{abstract}
Abstrak
Strategi dalam suatu pembelajaran terhadap peserta didik harus tepat kita perlu adanya pendekatan terhadap peserta didik agar kita dapat mengetahui setiap karakter anak, agar kita mudah untuk menentukan suatu model pembelajaran apa yang cocok untuk peserta didik yang akan di didik. Metode ini untuk mempermudah tenaga pendidik juga untuk tidak seenak memberikan model pembelajaran tanpa adanya pendekatan dan akan berakibat pada peserta didik jika kita salah memberi strategi.
\end{abstract}

Kata Kunci: Strategi pembelajaran, pendekatan pembelajaran, metode pembelajaran

\section{Abstract}

The strategy in learning for students must be appropriate. We need an approach to students so that we can know each student character, and then we can easily determine what learning model is suitable for students who will be educated. This method is to facilitate educators to not be as comfortable as giving learning models without an approach and will affect students if we give a wrong strategy.

\section{PENDAHULUAN}

Suatu pendiidikan dalam era globalisasi yang semakin maju ini sangat penting, tujuan dari penelitian ini untuk mengetahui pengaruh strategi pembelajaran dalam model pendekatan pada peserta didik dan kemampuan berpikir kreativ para peserta didik terhadap hasil belajar.

Strategi dalam konteks pendidikan dapat di maknai dengan perencanaan apa yang akan kita lakukan atau serangkaian apa yang akan kita capai yang mengarah pada tujuan pendidikan. Strategi dalam suatu konteks pendidikan mengarah kepadasuatu hal yang spesifik yaitu khusus pada pembelajaran. Srategi pembelajaran di gunakan oleh tenaga pendidik untuk mencapai tujuan pembelajaran secara efektif dan efisien (Suyadi, 2013: 13).

Salah satu model pembelajaran dengan nodel pendekatan pada peserta didik yang dapat mengaitkan mata pelajaran dengan kehidupan sehari hari adalah pembelajaran inkuiri dimana pendidik membimbing peserta didik dengan cara melakukan kegiatan pertanyaan awal dan mengarah kan pada suatu diskusi. Pembelajaran inkuiri kaya aktivitas pengajuan masalah dapat digunakan pendidik untuk pengembangan suatu pemikiran peserta didik lebih kreatif (Asy'ari, 2006:52).

Pemilihan dalam peggunaan berbagai macam strategi dan pendekatan menjadi hal yang sangat penting karena untuk menentukan kedepannya agar proses pembelajaran berjalan dengan baik. Sebab aspek kognitif dan afektif dalam tujuan pembelajaran memiliki karekteristik yang berbeda-beda namun saling berketaitan satu sam lain. Misalnya suatu ketika seora peserta didik memiliki kemampuan memecahkan masalah dengan baik dan tepat maka sesungguhnya dia telah memiliki kemampuan pemahaman yang baik dan tingkat kepercayaan diriyang tinggi (Aisyah, Ani :2016). 
Pendekatan dapat diartikan sebagai suatu titik tolak ukur pada sudut pandang kita terhadap proses pembelajaran. Pendekatan yang berproses pada pengajar atau guru menurunkan suatu strategi pembelajaran langsung, dan pembelajaran deduktif. Sedangkan pembelajaran yang berfokus pada peserta didik menurunkan suatu srategi pembelajaran discovery dan inkuiri dan pembelajaran induktif (Sanjaya, 2008: 127).

Pada sebagian para pendidik mendokrin bawwa pendidikan lebih bermakna sebagai suatu proses transfer pengetahuan dari seorang guru kepada muridnya secara utuh dan mentah tanpa memperhatikan bagaimana pengetahuan itu dapat dipahami dengan jelas oleh seorang murid atau siswa. Kondisi seperti inilah yang akhirnya akan mematikan pola pikirkreatif pada seorang murid dan yang akhirnya menanamkan stigma penolakan dan penilaian tentang penting tidaknya suatu materi bagi diri murid itu sendiri, sebab peserta didik merasa hanya "terpaksa" menjalaninya. Kondisi ini tidak akan menumbuh kembangkan kekreatifan peserta didik itu sendiri dan ke aktifan belajar dan mutu belajar serta hasil belajar peserta didik yang di harapkan (Na'im, Ahmad :2016).

Pendekatan konsep adalah suatu konsep dimana pengajaran yang secara langsung menyajikan konsep tanpa memberi kesempatan pada peserta didik untuk menghayati bagaimana konsep itu diperoleh. Konsep yang diperoleh dari fakta real, peristiwa, pengalaman, dan melalui generalisasi serta berfikir abstrak. Konsep yang memiliki banyak arti tetapi dalam kegiatan belajar mengajar, konsep merupakan akibat dan suatu hasil belajar, misal pada suatu saat peserta didik mengenal kesimpulan benda benda dengan jalan membedakan satu sama lain. Jalan lain yang dapat di tempuh adalah memasukkan suatubenda kedadalam suatu kelompok tertentu dan mengemukakan beberapa contoh dan kelompok tersebut dinyatakan sebagai jenis kelompok tersebut. Jalan yang kedua inila yang memungkinkan seorang peserta didik mengenal suatu benda atau peristiwa sebagai suatu anggota kelompok (Sagala, 2012: 71).

Pada model pembelajaran pendekatan pada seorang peserta didik ini dilatar belakangi oleh suatu konsep konsep dasar belajar menurut teori Naturalisme-Romantis dan teori kognitif gestal. Naturalisme-Romantis menekankan kepada keatifan peserta didik. Sedangkan teori kognitif gestal menekankan pemahaman dan kesatupaduan yang menyeluruh (Afrial,2012:121).

\section{METODE PENELITIAN}

Metode merupakan cara yang dipakai untuk membahas dan meneliti masalah. Metode yang digunaka dalam artikel ini menggunakan studi literature

Penelitian dilakukan secara studi literatur dengan meneliti dan menganalisia serta menelaah beberapa sumber buku dan jurnal terakait dengan strategi pembelajaran dengan model pendekatan pada peserta didik. Metode review literature ini bertujuan meminimalisir waktu yang terbuang untuk melakukan penelitian.

\section{HASIL DAN PEMBAHASAN}

Pada perkembangan zaman yang seamkin modern terutama pada era globalisasi menuntut agar sumberdaya manusia berkualitas tinggi. Untuk mendapatkan sumberdaya manusia yang berkualitas tinggi diperlukannya pendidikan yang baik. Dalam suatu pembelajaran dibutuhkan suatu strategi pembelajaran untuk memudahkan tenaga pendidik mencapai tujuan pembelajaran tersebut. Strategi dalam 
konteks suatu pendidikan dapat diartikan sebagai suatu perencanaan yang berisi atas rangkaian kegiatan yang didesain untuk mencapai tujuan pendidikan. Dalam strategi pembelajaran perlu adanya model, yang diartikan model yaitu gambaran kecil atau miniature dari suatu konsep besar pembelajaran secara keseluruhan.

Memasuki abad ke 21 pendidikan di Indonesia muali merasakan keterbalakangan pendidikan. Seab gelombang globalisasi dirasakan kuat terbuka. Kemajuan teknologi dan perubahan yang terjadi memberikan kesadaran baru bahwa Indonesia tidak lagi berdiri sendiri. Saat ini ketertinggalan yang paling Nampak yaitu dalam mutu pendidikan, baik formal maupun informal. Pendidikan memang telah menjadi oenopang dalam meningkatkan sumber daya manusia yang berkualitas tinggi untuk pembangunan bangsa, oleh karena itu tenaga pendidik harus dapat meningkatkan sumber daya manusia yang tidak kalah saing sumber daya manusia Negara lain.

Strategi selanjutnya perlu adanya pendekatan bahwa strategi maupun metode bersumber pada dua pendekatan dalam pembelajaran, yaitu pendekatan yang berpusat pada guru dan yang kedua pendekatan yang berpusat pada peserta didik. Strategi selanjutnya perlu adanya metode atau cara sebagai suatu cara atau prosedur yang ditempuh tenaga pendidik untuk mencapai tujuan pembelajaran. Yang terakhir tekhnik, tehnik maupun taktik mengajar merupakan penjabaran dari metode pembelajaran, dengan begitu teknik pembelajaran adalah salah satu cara yang ditempuh seorang pendidik untuk mengimplementasikan metode pembelajaran tertentu.

Peserta didik umumnya lebih tertarik dengan metode yang mampu memmbuat suatu interaksi dan komunikasi antara pendidik dan peserta didik dapat terjalin. Walaupun ceramah merupakan metode yang biasa digunakan oleh pendidik dan kurang diminati oleh peserta didik namun kita seorang calon pendidik harus dapat membawakan materi pembelajaran dengan baik, serta diselingi dengan canda tawa yang dapat membuat peserta didik menyukai cara mengajar kita. Selain metode pembelajaran yang digunakan dalam kegiatan belajar mengajar, pendidik juga yang ingin mencapai profesionalisme guru harus maampu memanfaatkan media pembelajaran yang ada untuk menunjang kegiatan belajar mengajar media tersebut disesuaikan dengan metode yang digunakan dalam mengajar.

Pada dasarnya, suatu pembelajaran merupakan proses komunikasi antara pendidik dan peserta didik. Proses komunikasi yang terjalin tidak akan selamanya berjalan dengan baik dan lancer, bahkan aka nada suatu proses komunikasi yang dapat menimbulkan salah presepsi atau pengertian maupun salah konsep. Untuk itu kita seorang pendidik hendaknya memakai strategi pembelajaran yang tepat sehingga dapat mendukung proses belajar mengajar. Untuk mempermudah strategi apa yang cocok untuk peserta didik kita perlu adanya pendekatan terlebih dahulu pada peserta didik agar kita tahu karakter stiap peserta didik. Setelah adanya pendekatan kita akan tahu beberapa karakter pada setiap peserta didik tersebut, dari situlah kita dapat menentukan strategi atau model pembelajaran apa yang cocok untuk peserta didik tersebut.

Pada saat pemilihan pendekatan dan metode kita harusbenar dan tepat sesuai dengan karakter dan sifat materi yang akan disampaikan pada saat 
pembelajaran, sehingga tidak akan menghalangi kelancaran jalannya proses pembelajaran. Oleh karena itu, baik pendekatan maupun metode yang digunakan oleh pendidik dapat dikatakan berhasil apabila dengan pendekatan dan metode tersebut dapat dicapai tujuan yang diharapkan. Dalam proses belajar mengajar pendekatan filosofi dapat diaplikasikan ketika guru mengajar, misal proses terjadinya alam atau manusia, darimana manusia berasal, bagaimana proses kejadiannya sampai terciptanya bentuk manusia. Hal ini terus berlangsung sampai batas maksimal pemiiran manusia.

Berdasarkan pendekatan pembelajaran ini, materi yang dipersiapkan untuk pembelajaran kepada peserta didik adalah materi yang sesuai dengan kebutuhan peserta didik dalam kehidupan bermasyarakat. Karena harus disadari juga sepenuhnya bahwasannya materi pembelajaran yang disampaikan kepada peserta didik tidak sekedar hanya untuk memajukan aspek kognitifnya saja, namun juga untuk kelangsungan hidupnya dimasa mendatang. Adapun juga pendekatan secara emosional yaitu usaha untuk menggugah perasaan dan emosi peserta didik dalam mayakini, memahami, dan menghayati materi yang diajarkan. Melalui pendekatan emosional, setiap pendidik harus berusaha untuk membakar semangat peserta didik dalam melaksanakan pembeljaran yang sesuai dengan tujuan pembelajaran tersebut. Pendekatan emosional meliputi hubungan antara peserta didik dan pendidik serta hubungan anatara peserta didik dan peserta didik. Didalam hal ini, pendidik merupakan kunci pengembangan hubungan tersebut. Oleh sebab itu, seharusnya pendidik mengembangkan iklim atau kondisi kelas yang baik melalui pemeliharaan hubungan antar pribadi di kelas. Untuk terciptanya hubungan pendidik dengan peserta didik yang positif, sikap mengerti dan sikap mengayomi atau sikap melindungi.

Strategi pembelajaran merupakan upaya seorang tenaga pendidik untuk menggerakkan peserta didik agar mau melakukan aktivitas pembelajaran, strategi pembelajaran bukanlah kegiatan yang sederhana, setiap langkahnya pembelajaran disertai penggerakan segala kemampuan untuk pencapaian tujuan pembelajaran. Pada dasarnya pembelajaran dengan model pendekatan memiliki kelebihan. Siswa dapat berpartisipasi aktif dalam pembelajaran yang disajikan, menumbuhkan sikap inquiry, mendukung kemampuan problem solving peserta didik, dan memberikan suatu wahana interaksi antar siswa maupun dengan pengajar, serta materi yang dipelajari dapat mencapai tingkat kemampuan yang lebih lama membekas karena peserta didik dilibatkan dalam proses menemukannya.

Salah satu bentuk pendekatan pembelajaran yang menekankan pada pemberian suatu pengalaman langsung atau riil dan yang berpusat pada peserta didik merupakan strategi pembelajaran inquiry. Metode ini kegiatan pembelajarannya menekankan pada suatu proses berfikir kritis untuk mencari dan menemukan sendiri jawaban dari suatu permasalahan yang dipertanyakan . proses berpikir inilah yang biasanya dilakukan melalui Tanya jawab antara peserta didik dan pendidik. Untuk memecahkan masalah, perlu adanya syarat awal atau kemampuan awal yang dimiliki oleh oeserta didik sehingga dapat dihubungkan dengan meteri pembelajaran yang baru untuk emecahkan suatu permasalahan yang baru. Pemecahan masalah dapat juga dimaknai sebagai penemuan langkahlangkah untuk mengatasi kesenjangan 
yang ada. Sedangkan kegiatan pemecahan suatu masalah ini sendiri merupakan kegiatan manusia dalam menerapkan konsep-konsep dan aturanaturan yang diperoleh sebelumnya.

Dalam model pembelajaran pendekatan perlu adanya pembelajaran yang menarik, agar konsep belajar yang membantu pendidik mengaitkan antara materi yang diajarkan dengan situasi dunia nyata peserta didik dan mendorong peserta didik utuk membuat suatu hubungan antara pengetahuan yang dimilikinya dengan menerapkan dalam kehidupan mereka sehari-hari, jadi pembelajaran yang menarik adalah proses pendidikan yang holistic dan bertujuan memotivasi peserta didik untuk memahami makna materi [elajaran yang dipelajarinya dengan mengaitkan materi pembelajaran tersebut dalam konteaks atau permasalahan kehidupan mereka seharihari sehingga peserta didik memiliki kemampuan atau keterampilan secara fleksibel dan dapat diterpakn dari pemasalahan lain ke permasalahan lainnya.

Menerapkan model pembelajaran yang menaik harus sesuai dengan kondisi dimana tempat peserta didik itu berada.kemudian melakukan evaluasi komprehensif yang tidak hanya mengukur kemampuan penguasaan bahan pembelajaran namun juga kemampuan dalam berfikir sera menciptakan model pembelajaran yang lebih variatif dan merangsang. Strategi mengajar yang diterapkan dalam suatu pembelajaran dikatakan efektif apabila menhasilkan sesuatu yang sudah sesuai dengan apa yang diharapkan atau dengan kata lain telah tercaainya tujuan tersebut. Sedangkan strategi mengajar dikatakan efisien jika penerapannya dalam menghasilkan sesuatu yang diharapkan itu relative menggunakan tenaga, usaha pengeluaran biaya, dan waktu yang dikeluarkan maka semakin efesien strategi tersebut.

Model pembelajaran pendekatan pada peserta didik adapun tehnik yang dapat dilakukan dalam proses pembelajaran itu menyesuaikan diri dengan para peserta didik. Lalu mendengarkan itu penting bilamana sedang mendengarkan seseorang usahakan agar tidak dengan segera melakukan evaluasi tentang apa yang sedang dikatakan. Upayakan untuk memahami apa yang dimaksud sebenarnya menurut perspektif orang lain, menyadari apa yan g sedang terjadi dalam pembelajaran, lalu menguji asumsi-asumsi hubungan dalam komunikasi dan hubungan interpersonal terbangun berdasarkan pada asumsi yang dibuat oleh masing-masing pihak satu sama lain. Yang terakhir memberikan umpan balik, pola dan cara berbicara, menyusun dan mengajukan pertanyaan. Tujuan digunakannya strategi pendidikan adalah penyediaan fasilitas bagi bermacam-macam kegiatan belajar siswa dalam lingkungan sosial, emosional, dan intelektual dalam kelas. Fasilitas yang tersedia memungkinkan peserta didik belajar dan beraktifitas, terciptanya interaksi sosial yang emberikan kepuasan, suasana disiplin, perkembangan intelektual, emosional dam sikap, serta apresiasi pada peserta didik.

Berdasarkan penjabaran diatas strategi pendidik berkaitan erat dengan pengaturan suasana pembelajaran dalam mencapai suatu tujuan pembelajaran. Hal ini merupakan tugas seorang pendidik untuk menciptakan suati suasana yang dapat menimbulkan suatu gairah belajar, meningkatkan prestasi belajar siswa, meningkatkan mutu pembelajaran dan lebih memungkinkan pendidik memberikan bimbingan terhadap peserta didik dalam proses 
pembelajaran, sehinnga diperlukan pengoganisasian kelas yang memadai. Sedangkan fungsi dari strategi pembelajaran merupakan proses perubahan-perubahan dalam organisasi kelas sehingga setiap peserta didik mau bekerjasama dan mengembangkan control mereka sendiri. Kerja sama dalam kelas tanpak dengan adanya kekompakkan untuk semangat belajar.

Pendidik sebagai pengelola kelas telah menerapkan beberapa pendekatan dalam pengelolaan kelas yaitu pendekatan kekuasaan yang dimaknai pendidik menciptakan dan mempertahankan situasi disiplin dalam kelas. Kedisiplinan adalah kekuatan yang menuntut peserta didik untuk mentaatinya di dalam kelas ada kekuasaan dan norma yang mengikat untuk ditaati anggota kelas. Selanjutnya pendekatan kerja kelompok, dalam pendekatan ini pendidik harus menciptakan kondisi yang memungkinkan kelompok yang produktif dan juga harus dapat menjaga kondisi agar tetap kondusif.

Kemudian pendekatan elektis, pendekatan elektis ini menekankan pada potensialitas, kreatifitas, dan inisiatif pendidik dalam memilih berbagai pendekatan tersebut berdasarkan situasi yang dihadapinya. Penggunaan pendekatan tersebut dalam suatu situasi yang memungkinkan untuk dipergunakan salah satu dab dalam situasi lain mungkin harus mengkombinasikan beberapa pendekatan tersebut. Pendekatan elektis ini juga dimaknai yaitu pengolahan kelas yang beusaha menggunakan berbagai macam pendekatan yang memiliki potensi untuk dapat menciptakan dan mempertahankan suatu kondisi proses belajar mengajar yang kondusif, efektif, dan efisien.

Pendidik berhak secara bebas memilih pendekatan terhadap peserta didik sesuai dengan kemampuan dan selama maksud dan penggunaannya untuk pengelolaan kelas, kegiatan pendidik untuk menciptakan dan mempertahankan kondisi kelas yang kondusif menurut pendapat lain, adaya pendekatan ancaman atau intimidasi ini pengelolaan kelas juga sebagai proses untuk mengontrol pada tingkah laku peserta didik. Pendekatan perubahan tingkah laku sebagai suatu proses untuk mengubah tingkah laku peserta didik. Pendekatan ini berdasarkan perubahan terhadap tingkah laku ini bertolak belakang terhadap pandangan psimologi behaviora. Pendekatan kebebasan, merupakan pendekatan proses untuk membantu peserta didik agar merasa bebas untuk mengerjakan sesuatu kapan saja dan dimana saja.

Keberhasilan dalam strategi pembelajaran merupakan suatu keberhasilan dalam suatu proses belajar mengajar, yang pada dasarnya merupakan perubahan positif selama dan sesudah proses belajar mengajar dilaksanakan. Keberhasilan belajar mengajar dapat kita lihat dalam keterlibatan peserta didik secara aktif selama proses pembelajaran berlangsung. Keberhasilan dalam pengajaran tidak hanya dipandang dari hasil pembelajaran yang dicapai oleh pserta didik, bamun dilihat dari segi proses dalam pembelajaran peserta didik tersebut. Sebab hasil dari belajar merupakan implikasi dari proses pembelajaran yang sebelumnya telah direncanakan bagaimana pelaksanaannya dalam prigram perencanaan pembelajaran yang terdapat dalam tujuan pembelajaran yang ingin tercapai sebagai tolok ukurnya.

Proses belajar mengajar tak lepas juga dari berbagai komponen yang ada didalamnya diantaranya yaitu tujuan pengajaran, bahan pengajaran, metode 
dan alat, kegiatan belajar siswa, dan kegiatan mengajar pendidik dan penilainan. Dalam pelaksanaanya tak lepas dari guru sebagai seorang pedidik dan siswa sebagai anak didik. Proses belajar mengajar akan terjadi apabila terdapat komunikasi yang baik diantara kedua belah pihak. Dengan demikian keberhasilan dalam proses pembelajaran sebagian besar ditentukan oleh efektifitas dan efesiensi dalam proses pembelajaran. Dikatakan apabila tujuan pembelajaran tersebut tercapai. Tolok ukur untuk mengatakan proses belajar mengaar dinilai berhasil berdasarkan dengan kurikulum yang digunakan.

Keadaan ini menunjukkan penerapan pendekatan terhadap peserta didik pada proses pembelajaran dapat membantu peserta didik memahami materi. Penerapan pendekatan model pembelajaran tersebut memudahkan peserta didik memahami materi pembelajaran.

\section{SIMPULAN}

Pendekatan dan metode merupakan salah satu aspe komponen penting dalam system pembelajaran. Sebaik apapun materi pembelajran yang telah disiapakan atau yang direncanakan, jika tana adanya pendekatan dan metode serta srategi yang tepat dan baik maka proses belajar dan mengajar itu bisa menuai kegagalan, karena dengan proses pendekatan pendidik tau karakter dari setiap individu peserta didik jadi kita dapat dengan mudah menentukan model pembelajaran apa yang cocok untuk peserta didik agar mudah dipahami dan di terima oleh peserta didik materi yang di sampaikan si pendidik. Oleh karena itu, kemampuan menerapkan pendekatan dan strategi sangat menentukan.

Pentingnya pendekatan dan strategi dalam proses pembelajaran dalam pendidikan, maka pendidik dituntut profesionalitasnya dalam mengembangkan pendekatan dan strategi tersebut. Pendidik jua harus mengetahui keunggulan dan kelemahan masing-masing model pendekatan dan strategi yang akan digunakan serta menentukan yang paling tepat sehingga peserta didik dapat lebih aktif dan kritis dalam proses pembelajran dan yang paling penting dalam strategi pembelajaran dengan model pendekatan ini dapat dengan mudah apa yang jadi tujuan dalam pendidikan tercapai dengan baik.

\section{SARAN}

Untuk penulis agar lebih banyak memperbanyak literatur agar semakin akurat apa yang ditulis.

\section{UCAPAN TERIMA KASIH}

Terimakasih kepada para pihak yang sudah menyemangati untuk menyelesaikan tugas artikel ini dengan baik dan lancar serta tidak adanya kendala.

\section{DAFTAR PUSTAKA}

Afrial, Ahmad. 2012. Strategi Belajar Mengajar. Bandung: PT. Refika Aditama

Aisyah, Ani. 2016. Pendekatan induktif untuk meningkatkan kemampuan generalisasi dan self confident siswa smk. Jurnal Penelitian Pendidikan dan Pengajaran Matematika. Universitas Indonesia. Bandung. Volum 2 nomor 1, pp.112.

Asy'ari, dkk. 2006. Ilmu PengetahuanbSosial SD. Jakarta: Erlangga.

Na'im, Ahmad. 2016. ALIKASI COOPERATIF LEARNING TIPE GROUP INVESTIGATION (GI) PADA MATA PELAJARAN SEJARAH KEBUDAYAAN 


\section{ISLAM DIKELAS V FAVORIT}

MI SALAFIYAH SYAFI'IYAH.

Paron Ngawi. Volime 3, Nomer 1.

ISSN 2406-775X.

Sagala, Saeful. 2003. Konsep dan Makna Pembelajaran. Bandung: PT. Alfabeta.

Sanjaya W. 2011. Strategi Pembelajaran Berorientasi Standart Proses Pendidikan. Jakarta: Kencana Prenada Media.

Suyadi. 2013. Strategi Pembelajaran Pendidikan Karakter. Bandung : PT Remaja Rodakarya. 